\title{
Ecophysiological interactions in species of peacock bass Cichla spp. from the Amazon
}

The peacock bass species Cichla spp. are economically important in the Amazon region, being used in food, sport fishing and the ornamental fish market. The aims of present study was investigate the ecophysiological interactions and the relationship to the physical parameters of the water. In order to compare and ecologically correlate the species of peacock bass (Cichla monoculus, Cichla temensis and Cichla vazzoleri) in Lake Balbina, Presidente Figueiredo. The total of 45 animals, 15 individuals of each species, was captured with rod and reel, hand line with natural and artificial bait. The animals blood was removed by means of caudal puncture and the hematological data were determined according to methodology previously described in the literature. The analysis of water physical properties was determined during the collections. The Principal Component Analysis (PCA) was used for observations of interactions (60.00\%). The PCA of the erythrogram showed an interaction of $86.26 \%$, the thrombogram and leukogram of the peacock bass species showed no interaction. The PCA of the plasma metabolites showed no interaction with a rate of $51.55 \%$, however, there is a tendency in the $\mathrm{x}$ axis, where the species $\mathrm{C}$. monoculos presents distinct ecophysiological patterns of $\mathrm{C}$. temensis and C. vazzoleri. In the analysis of the physical properties of the water, was observed interaction $96.59 \%$, where in the $X$ axis the species $C$. monoculos and C. vazzoleri inhabit exclusive localities. It is possible to infer that C. monoculos presents a different pattern compared to other species.

\section{Interações ecofisiológicas em espécies de tucunaré Cichla spp. da Amazônia}

\begin{abstract}
As espécies de tucunaré Cichla spp. são economicamente importantes na região amazônica, pois são utilizadas na alimentação, na pesca esportiva e no mercado de peixes ornamentais. O presente estudo tem como objetivo investigar as interações ecofisiológicas e as relações dos parâmetros físicos da água. Comparação e correlação entre as espécies de tucunaré (Cichla monoculus, Cichla temensis e Cichla vazzoleri) do Lago Balbina, Presidente Figueiredo. No total, 45 animais, 15 animais de cada espécie, foram capturados com vara, molinete e linha de mão com iscas naturais e artificiais. $O$ sangue dos animais foi extraído por punção cauda e os dados hematológicos foram determinados de acordo com a metodologia previamente descrita na literatura. A análise das propriedades físicas da água foi determinada durante a amostragem. A análise de componentes principais (PCA) foi utilizada para observar interações (60,00\%). O eritrograma do PCA mostrou $86,26 \%$ de interação, o trombograma e o leucograma das espécies de tucunaré não apresentaram interações. O PCA dos metabólitos plasmáticos também não apresentou interação, porém, existe uma tendência no eixo $\mathrm{x}$ das espécies de $\mathrm{C}$. monoculos que mostrou diferenciação ecofisiológica de $\mathrm{C}$. temensis e $\mathrm{C}$. vazzoleri. $\mathrm{Na}$ análise das propriedades físicas da água, observou-se uma interação de $96,59 \%$, onde no eixo X as espécies C. monoculos e C. vazzoleri, habitam locais exclusivos. Pode-se inferir que C. monoculos apresenta um padrão diferente em comparação com outras espécies de tucunarés investigadas.
\end{abstract}

Palavras-chave: Sangre; Associação; Fisiologia; Peixes.

Topic: Uso de Recursos Naturais

Reviewed anonymously in the process of blind peer.
Received: 09/08/2020

Approved: 25/09/2020
Philip Dalbert da Silva Castro (iD Universidade Federal do Amazonas, Brasil http://lattes.cnpq.br/4467305614845153 http://orcid.org/0000-0002-9739-6130 philip_engpesca@outlook.com

Daniel da Silva Ladislau (id

Estadual do Oeste do Paraná, Brasil http://lattes.cnpq.br/8098824072487689 http://orcid.org/0000-0002-0467-6353 daniel-ladislau@hotmail.com

Maiko Willas Soares Ribeiro (id

Instituto Nacional de Pesquisas da Amazônia, Brasil http://lattes.cnpq.br/6299874319353966 http://orcid.org/0000-0002-6155-5646 maikowillas@hotmail.com

Antônia Jaqueline Vitor de Paiva (D)
Instituto Federal do Amazonas, Brasil
http://lattes.cnpq.br/8033494354734324
$\begin{aligned} & \text { http://orcid.org/0000-0003-4793-4903 } \\ & \text { jack.paiva.15@gmail.com }\end{aligned}$
Ariany Rabello da Silva Liebl 10
Universidade Federal do Amazonas, Brasil
http://lattes.cnpq.br/7556366980080450
http://orcid.org/0000-0002-5010-1294
ny.rabello@gmail.com
Jackson Pantoja Lima (D)
Instituto Federal do Amazonas, Brasil
http://lattes.cnpq.br/1227404149595373
http://orcid.org/0000-0002-6449-4981
jackson.lima@ifam.edu.br

Paulo Henrique Rocha Aride (iD) Instituto Federal do Amazonas, Brasil http://lattes.cnpq.br/9087696929404160 http://orcid.org/0000-0001-9752-5003 aride@ifam.edu.br

Adriano Teixeira de Oliveira Instituto Federal do Amazonas, Brasil http://lattes.cnpq.br/9164471794674935 http://orcid.org/0000-0003-4988-9878 adriano.oliveira@ifam.edu.br

\section{Referencing this:}

CASTRO, P. D. S.; LADISLAU, D. S.; RIBEIRO, M. W. S.; PAIVA, A. J. V.; LIEBL, A. R. S.; LIMA, J. P.; ARIDE, P. H. R.; OLIVEIRA, A. T..

Ecophysiological interactions in species of peacock bass Cichla spp. from the Amazon. Revista Ibero Americana de Ciências Ambientais, v.11, n.5, p.594-599, 2020. DOI: http://doi.org/10.6008/CBPC21796858.2020 .005 .0053 


\section{INTRODUCTION}

Among the members of the Amazon peacock bass ichthyofauna Cichla spp. show great economic, ecological and social importance, because sport fishing that occurs in the Middle Negro River (Barcelos) and along the Uatumã River, including the Balbina Reservoir (CASTRO et al., 2020). The peacock bass are also appreciated for flavor, due to its organoleptic characteristics of your meat, considered being very tasty. In addition, these species also feature ornamental fish market attractiveness, as present large variations in their patterns of coloration.

The species of peacock bass feature great adaptability in reservoirs, as demonstrated over the years in the Balbina dam. In this location, three species are found, they are: Cichla temensis, Cichla monoculos and Cichla vazzoleri. The main differences between the species are the patterns of colors and sidelines differentiation. Individuals of $C$. monoculus showed relevant feature that facilitates your identification, which is the presence of a horizontal solid stain or even interrupted, at the height of the base of the pectoral fin (SANTOS et al., 2006). Feature a sideline discontinues on both sides, being the species with greater geographical distribution (KULLANDER et al., 2006).

Individuals of $C$. temensis stand out by size, reaching up to $80.0 \mathrm{~cm}$ and more than $11 \mathrm{Kg}$ (SANTOS et al., 2006). This species presents distribution restricted to black water rivers and its tributaries (KULLANDER et al., 2006). The specie $C$. vazzoleri is the species with smaller geographic distribution, with presence in the State of Pará in the northern region (Oriximiná) at the mouth of the Cuminá River, the rivers Uatumã and Trombetas, as well as the Balbina (KULLANDER et al., 2006). Has coloration yellow gold, red eyes and black vertical bars. Adult individuals can reach $70 \mathrm{~cm}$ long and weigh about $7 \mathrm{~kg}$ of (KULLANDER et al., 2006).

Although the meristic and morphological differences exist between the species cited, there is no research on the interactions and differences between hematological aspects and the characteristics of the water of their natural occurrence. Thus, the aim of present work is elucidating the hematological profile (hematology, thrombogram and leukocyte count and plasma metabolites) in relation to the physical parameters of the water, comparing and correlating ecologically between the peacock bass $C$. monoculus, $C$. temensis and C. vazzoleri.

\section{MATERIALS AND E METHODS}

The Balbina Lake this study site is located in the municipality of President Figueiredo (Amazonas, Brazil). The Balbina Hydroelectric Power Plant was built in the decade of 1980 with the Uatumã River Dam the $155 \mathrm{~km}$ from the city of Manaus. In the year 1990, the Uatumã River Biological Reserve (REBIO) was created with the goal of protecting the flora and fauna of the rivers Uatumã and Jatapu. The REBIO is located on the left bank of the reservoir of Balbina, covering the municipalities of São Sebastião of Uatumã, Urucará and Presidente Figueiredo.

A total of 45 animals were catches using fishing rod, reel, line with natural bait and artificial. Were captured 15 individuals of $C$. monoculos, 15 of $C$. temensis and 15 from $C$. vazzoleri. After the capture the 
blood was collected immediately through the caudal puncture. Was subsequently held biometrics determining the overall length $(\mathrm{CT}, \mathrm{cm})$ with the use of tape and the body weight $(\mathrm{g})$ with the use of portable scales. After the procedures of handling the animals were returned to the environment.

The collection of blood was performed with the aid of disposable syringes containing heparin 5000 UI. With the blood samples were determined the hematocrit $(\mathrm{Ht}, \%)$ through the microhematocrit method (capillary tubes containing heparin), the count of red blood cells (RBC, million/ $\mathrm{mm}^{3}$ ), through the optical pickup in Neubauer Chamber in formalin-fixed specimens-citrate. The blood hemoglobin concentration ( $\mathrm{Hb}$, $\mathrm{g} / \mathrm{dL}$ ) was determined by the cianometahemoglobin method and hematological indices: mean corpuscular volume ( $\mathrm{MCV}, \mathrm{fL})$, mean corpuscular hemoglobin $(\mathrm{MCH}, \mathrm{pg})$ and mean corpuscular hemoglobin concentration (MCHC, g/dL) were calculated in accordance with methodology of Wintrobe (1934). Blood extensions were prepared in field and stained in the laboratory to the total count of leukocytes and thrombocytes (DIAS, 2006), as well as for the differential leukocyte count based on 100 count leukocyte types and subsequent determination of the percentage of each cell type.

After the blood separation by centrifugation at $12000 \mathrm{G}$, plasma samples were immediately frozen in liquid nitrogen until the moment of laboratory testing. Glucose levels $(\mathrm{g} / \mathrm{dL})$, total protein $(\mathrm{g} / \mathrm{dL})$, triglycerides $(\mathrm{mM} / \mathrm{L})$, cholesterol $(\mathrm{mM} / \mathrm{L})$ and urea $(\mathrm{mM} / \mathrm{L})$ were determined with the use of enzymatic kits Labtest ${ }^{\circledR}$ and analyzed in spectrophotometer. Also the plasma metabolites were determined $(\mathrm{mM} / \mathrm{L})$, potassium $(\mathrm{mM} / \mathrm{L})$ and chlorides $(\mathrm{mM} / \mathrm{L})$, with the use of enzymatic kits labtest ${ }^{\circledast}$ and analyzed in spectrophotometer. Water samples for the evaluation of physical properties such as temperature $\left({ }^{\circ} \mathrm{C}\right), \mathrm{pH}$ and dissolved oxygen $(\mathrm{mg} / \mathrm{L})$, were determined in capture locations using digital multi-parameter WTW-310i (WTW, Germany).

For investigation of hematological aspects and interactions of physical properties of water was employed multivariate exploratory statistics through Principal Component Analysis (PCA). These analyses were divided in hematology ( 6 variables), thrombogram and leukogram (6 variables), plasma metabolites (8 variables) and physical properties of water (3 variables), the interactions were considered to be significant when the sum of the $X$ and $Y$ axes were greater than or equal to $60.0 \%$.

\section{RESULTS AND DISCUSSION}

The results of the total length and body weight are shown in Table 1. The Table 1 demonstrate that individuals of the species $C$. monoculos have smaller total length and greater body weight.

Table 1: Biometrics (mean \pm standard deviation) of three species of peacock bass Cichla spp. from Balbina Lake, Presidente Figueiredo, Amazon.

\begin{tabular}{llll}
\hline Variables & C. monoculos & C. temensis & C. vazzoleri \\
\hline Total length $(\mathrm{cm})$ & $26.20 \pm 1.42$ & $29.30 \pm 4.27$ & $28.20 \pm 6.83$ \\
Weight $(\mathrm{g})$ & $448.93 \pm 113.88$ & $408.33 \pm 183.24$ & $446.80 \pm 289.71$ \\
\hline
\end{tabular}

The erythrogram PCA (Figure 1) of peacock bass species showed an interaction of $74.27 \%$ (axis $x=$ $39.84 \%, y=34.43 \%)$. In relation to $X$ axis, can be observed that $C$. temensis and $C$. vazzoleri are species closer to $C$. monoculos. When the $\mathrm{Y}$ axis is analyzed the same characteristic of the $\mathrm{X}$ axis in which the concentrated "cloud" pattern is marked in $C$. monoculos, different from $C$. temensis and $C$. vazzoleri that have more 
expansive distribution. It is observed that the oxygen demand between a three species of peacock bass is differentiated. The specie $C$. monoculos has respiratory capacity differentiated from $C$. temensis and $C$. vazzoleri, although these species inhabit the same localities within the same ecosystem. In a study with elasmobranchs conducted by Oliveira et al. (2017) it is possible to observe that Potamotrygon wallacei has lower index of the red series when compare with Paratrygon aiereba stingray. In the other hand Potamotrygon motoro is a kind of intermediate patterns of red series, varied between the two species, but with greater similarity to the species $P$. aireba (OLIVEIRA et al., 2017). In study of Dias et al. (2011) with $C$. temensis from fish farms was described that the erythrogram analysis is associated with the respiratory capacity of fish.

The PCA of thrombogram and leukogram (Figure 2) of peacock bass species showed no interaction represented by only $50.73 \%$ ( $x$ axis $=29.31 \%, y=21.42 \%$ ). The PCA of thrombogram and leukogram showed no interaction ecophysiological, however, there is a trend in the $x$-axis of differentiation where $C$. monoculos is different from the other two species, but it is not possible to state that $C$. monoculos has a different immune system from the other two species. This trend may have been caused by some endogenous factor not considered in the present study. In a PCA investigated with freshwater stingrays, no interaction of the thrombogram and leukocytes (57.43\%) was observed in the immune system of the $P$. wallacei, $P$. motoro and $P$. aiereba stingrays (OLIVEIRA et al., 2017).

The PCA of the plasma metabolites (Figure 3) showed no interaction $51.55 \%$ (axis $x=29.01 \%, y=$ 22.54\%). The PCA of the plasma metabolites showed no interaction, however, there is a tendency in the $x-$ axis where $C$. monoculos seems to be a species with different ecophysiological patterns from $C$. temensis and $C$. vazzoleri. These characteristics are not confirmed since the three species of peacock bass are carnivorous, feeding mainly on fish (SANTOS et al., 2006; KULLANDER et al., 2006) and the plasma ion patterns are similar to other species of Amazonian fish.

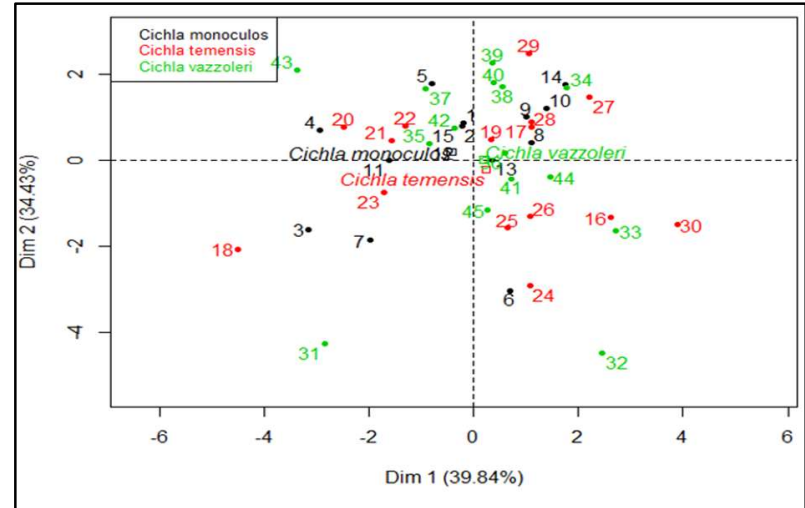

Figure 1: PCA Analysis of three species of peacock bass Cichla spp. erythrogram from Balbina Lake, Presidente Figueiredo, Amazon.

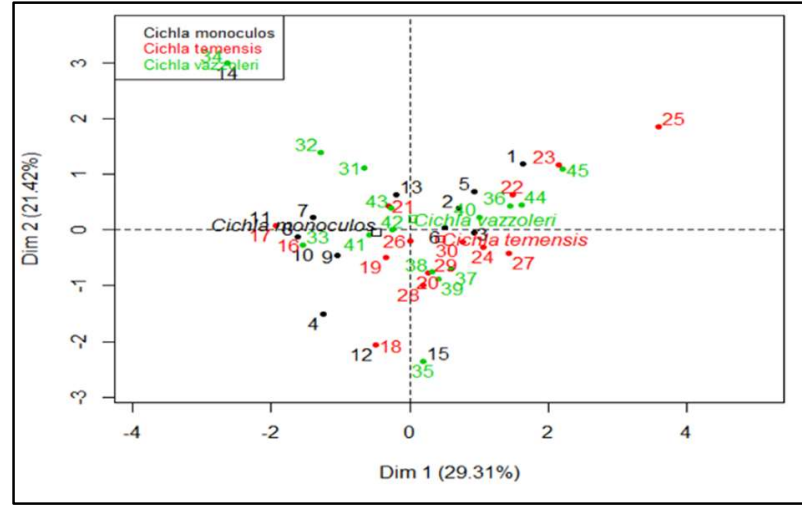

Figure 2: PCA Analysis of three species of peacock bass Cichla spp. thrombogram and leukogram from Balbina Lake, Presidente Figueiredo, Amazon.

In the PCA of the plasmatic biochemistry of Oliveira et al. (2017) we observed an ecophysiological interaction (64.67\%) where it is observed that the species $P$. aiereba is a differentiated species of $P$. motoro and $P$. wallacei. According to the authors, this difference is caused by eating habits. For the ions, these values 
have not reached the minimum level for the analysis (50.62\%) (OLIVEIRA et al., 2017).

In PCA analysis of physical properties of water (Figure 4) the interaction of $96.59 \%$ were observed ( $x$ axis $=63.29 \%, y=33.30 \%)$. In PCA analysis of physical properties of water the interaction of $96.59 \%$, we can see that the species $C$. monoculos and $C$. vazzoleri inhabit different localities. In other hand, overlaps were found with respect to water properties for the three peacock bass species described in the present study. The PCA of water properties of the places where the stingrays were caught, there was showing differentiation of $68.57 \%$ mainly along the $\mathrm{X}$-axis $(49.44 \%)$. These values indicate that the species $P$. motoro is distributed broadly across the environment, while the species $P$. aiereba interacts more narrowly over the positive portion of the X-axis (OLIVEIRA et al., 2017). In the present study the interactions in the $y$ axis show that the species $C$. vazolleri is more generalist than the other species.

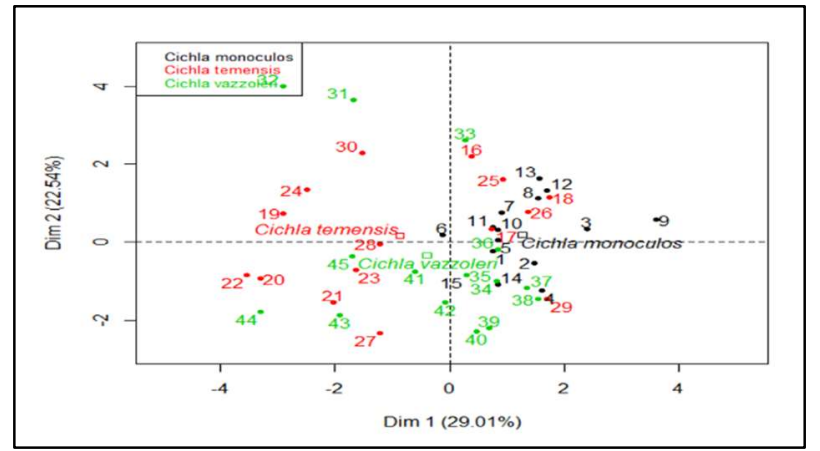

Figure 3: PCA Analysis of three species of peacock bass Cichla spp. plasma metabolites from Balbina Lake, Presidente Figueiredo, Amazon.

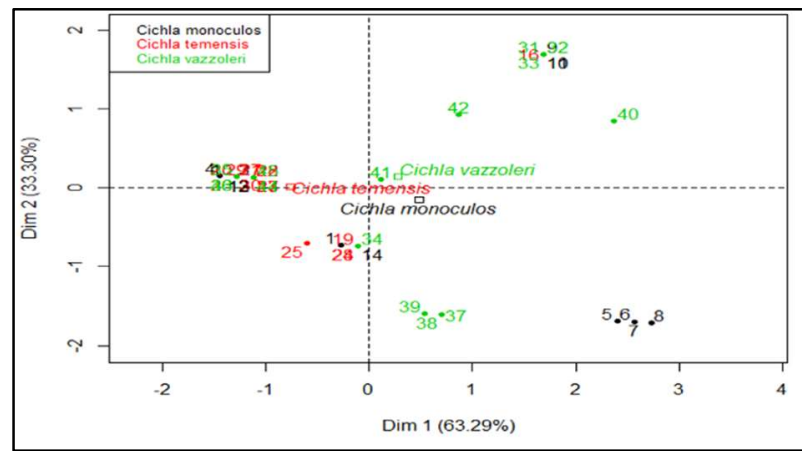

Figure 4: PCA analysis of of three species of peacock bass Cichla spp. water physical properties of from Balbina Lake, Presidente Figueiredo, Amazon.

\section{CONCLUSIONS}

According to the data collected and the PCA analyzes developed in the present study we can infer that the $C$. monoculos presents a different ecophysiological patterns when compare with the species $C$. temensis and $C$. vazzoleri. Thus, the specie $C$. monoculos should be managed and conserved under conditions differentiated from the other species described in the present study.

ACKNOWLEDGMENTS: The authors are grateful to the Support Program for Scientific Development and Technological Innovation (PADCIT) of the Federal Institute of Education, Science and Technology of Amazonas (IFAM) (proclamation nos. 008/2014 and 001/2016), for the projects 'Physiological parameters and Cichla spp. of Balbina lake: support for management and conservation and applicability for fish farming' and 'Monitoring of the welfare of fish of economic importance for the state of Amazonas'. PDSC, MWSR and ARSL are grateful for the granting of scholarships granted by the Coordination for the Improvement of Higher Education Personnel (CAPES). ATO is grateful for the award of the research grant awarded by IFAM.

\section{REFERENCES}

CASTRO, P. D. S.; LADISLAU, D.; RIBEIRO, M. W. S.; LOPES, A C. C.; LAVANDER, H. D.; BASSUL, L. A.; MATTOS, D. C.; LIEBL, A. R. S.; ARIDE, P. H. R.; OLIVEIRA, A. T.. Hematological parameters of three species of tucunarés (Cichla spp.) from
Lake Balbina, Presidente Figueiredo, Amazonas. Brazilian Journal of Biology, 2020. DOI:

https://doi.org/10.1590/1519-6984.219409 
KULLANDER, S. O.; FERREIRA, E. J. G.. A review of the South American cichlid genus Cichla, with descriptions of nine new species (Teleostei: Cichlidae). Ichthyological Exploration of Freshwaters, v.17, p.289-398, 2006.

OLIVEIRA, A. T.; ARAUJO, M. L. G.; PANTOJA-LIMA, J.; ARIDE, P. H. R.. Ecophysiological interactions and water-related physicochemical parameters among freshwater stingrays. Brazilian Journal of Biology, v.77, p.616-621, 2017.DOI: http://dx.doi.org/10.1590/1519-6984.01816

SANTOS, G. M.; FERREIRA, E. J. G.; ZUANON, J. A. S.. Peixes comerciais de Manaus. Manaus: Ibama, 2006.

DIAS, M.. A morphological and cytochemical study of erythrocytes, thrombocytes and leukocytes in four freshwater teleosts. Journal of Fish Biology, v.68, p.18221833, 2006. DOI: https://doi.org/10.1111/i.10958649.2006.01089.x

DIAS, M. T.; MONTEIRO, A. M. C.; AFFONSO, E. G.; AMARAL, K. D. S. Weight-length relationship, condition factor and blood parameters of farmed Cichla temensis Humboldt, 1821 (Cichlidae) in central Amazon. Neotropical Ichthyology, v.9, p.113-119, 2011. DOI: http://dx.doi.org/10.1590/S1679$\underline{62252011005000010}$

WINTROBE, M. M.. Variations on the size and hemoglobin content of erythrocytes in the blood of various vertebrates. Folia Haematologica, v.51, p.32-49, 1934

A CBPC - Companhia Brasileira de Produção Científica (CNPJ: 11.221.422/0001-03) detém os direitos materiais desta publicação. Os direitos referem-se à publicação do trabalho em qualquer parte do mundo, incluindo os direitos às renovações, expansões e disseminações da contribuição, bem como outros direitos subsidiários. Todos os trabalhos publicados eletronicamente poderão posteriormente ser publicados em coletâneas impressas sob coordenação da Sustenere Publishing, da Companhia Brasileira de Produção Científica e seus parceiros autorizados. Os (as) autores (as) preservam os direitos autorais, mas não têm permissão para a publicação da contribuição em outro meio, impresso ou digital, em português ou em tradução. 